\title{
Belajar Matematika dengan LKPD Berbasis Kontekstual
}

\section{Ni L. Pt Sri Radha Nareswari ${ }^{*}$, I Md Suarjana², Md Sumantri3}

\author{
1,2 Program Studi Pendidikan Guru Sekolah Dasar, Universitas Pendidikan Ganesha, Singaraja, Indonesia
}

\section{ART ICLE I N F O}

Article history:

Received March 09, 2021

Revised April 15, 2021

Accepted June 20, 2021

Available online August 25, 2021

Kata Kunci:

LKPD Berbasis Kontekstual, Matematika

Keywords:

Contextual-Based Worksheets, Mathematics

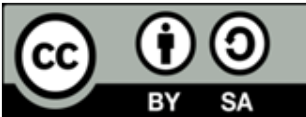

This is an open access article under the CC BY-SA license.

Copyright (ㄷ) 2021 by Author. Published by Universitas Pendidikan Ganesha.

\begin{abstract}
A B S T R A K
Permasalahan yang ditemukan di lapangan berdasarkan observasi yang dilakukan antara lain: siswa kurang memahami materi matematika, LKPD yang digunakan minim penjelasan materi, dan LKPD kurang kontekstual dan menarik bagi siswa. Penelitian ini bertujuan untuk mengembangkan LKPD dengan pendekatan kontekstual pada mata pelajaran matematika materi menentukan keliling dan luas bangun datar persegi, persegi panjang, dan segitiga di kelas IV SD serta mengetahui validitas produk yang telah dikembangkan. Penelitian ini merupakan penelitian pengembangan yang dilaksanakan dengan menggunakan model pengembangan ADDIE. Subjek penelitian yang digunakan dalam penelitian ini yaitu Lembar K erja Peserta Didik (LKPD) dengan Pendekatan Kontekstual Pada Materi Matematika di Kelas IV SD. Metode yang digunakan untuk mengumpulkan data yaitu metode wawancara dan kuesioner. Data yang diperoleh kemudian dianalisis dengan metode analisis deskriptif kualitatif dan kuantitatif untuk mengetahui validitas produk yang dikembangkan. Adapun nilai yang diperoleh yaitu: uji ahli mata pelajaran dosen matematika mendapatkan nilai $92 \%$, uji ahli mata pelajaran guru matematika mendapatkan nilai $97,3 \%$, uji ahli media pembelajaran mendapatkan nilai $90,9 \%$, dan uji coba perorangan mendapatkan rata - rata nilai $96 \%$. Dari keseluruhan nilai tersebut, dapat dikualifikasikan dalam kategori sangat baik. Berdasarkan analisis tersebut maka dapat dikatakan bahwa Lembar Kerja Peserta Didik (LKPD) yang dikembangkan valid dan dapat digunakan dalam pembelajaran di kelas IV Sekolah Dasar.
\end{abstract}

\section{A B S TRACT}

The problems that found based on the observation that have been done, including: students have a lack understanding of the mathematics matter, explanation of the material contained in the worksheet is minimal, and student worksheet iss less contextual also less interesting for students. This study aims to develop Student's Worksheets with a contextual approach to the mathematics subject, matter of determining the perimeter and area of squares, rectangles, and triangles in fourth grade of elementary school and to determine the validity of the products that have been developed. This research is a development research carried out using the ADDIE development. The research subjects used in this study were Student's Worksheets with a Contextual Approach to Mathematics in fourth Grade of elementary school. The method used to collect data are interviews and questionnaires. The data obtained were analyzed to determine the validity of the developed product. The scores obtained are: the mathematics teacher subject expert test scores 92\%, the mathematics teacher subject expert test scores $97.3 \%$, the learning media expert test scores $90.9 \%$, and individual trials get an average value of $94 \%$. From the overall score, it can be qualified in a very good category. Based on this analysis, it can be concluded that the Student's Worksheet that developed is valid and can be used in learning in fourth grade elementary school.

\section{PENDAHULUAN}

Proses pembelajaran merupakan suatu hal yang sangat penting bagi kehidupan. Hal ini disebabkan oleh adanya suatu pembelajaran akan memberikan suatu pengetahuan dan pengalaman baru. Pengetahuan ini dijadikan modal bagi siswa untuk mendapatkan pengetahuan baru dan juga digunakan untuk memecahkan suatu permasalahan (Pamungkas et al., 2017). Dalam suatu proses pembelajaran, hendaknya guru membiarkan siswa mengontruksi atau membangun pengetahuannya sendiri. Peserta 
didik diberikan kebebasan untuk mengutarakan pendapatnya dan guru bertugas untuk menyediakan suasana yang mendukung proses kontruksi siswa (Astriani, 2017; Sari, 2017). Dengan melibatkan siswa aktif belajar, maka dapat mengarahkan siswa untuk membentuk nilai-nilai bermakna dalam menjalani hidup (Surya et al., 2016). Proses pembelajaran yang baik haruslah memuat aspek interaktif yaitu interaksi antara siswa dengan guru, atau siswa dengan siswa agar belajar menjadi lebih menyenangkan, menantang, dan siswa dapat mengembangkan kreativitas dan kemandiriannya (Ambarini et al., 2013; Mustaqim \& Kurniawan, 2017). Dalam suatu proses pembelajaran, tentunya terdapat komponen pembelajaran. Salah satu komponen pembelajaran yang penting yaitu bahan ajar. Bahan ajar sangat penting digunakan dalam proses pembelajaran untuk meningkatkan efektivtas dan kualitas pembelajaran sehingga tujuan pembelajaran dapat tercapai (Gazali, 2016; Purmadi \& Surjono, 2016). Bahan ajar yang efektif tentu dapat menarik minat siswa untuk belajar dan kemudian akan berdampak pada hasil belajar yang meningkat (Fahrurrozi et al., 2021). LKPD (Lembar Kerja Peserta Didik) merupakan salah satu bahan ajar yang dapat digunakan oleh guru untuk menunjang proses pembelajaran agar lebih menarik dan kreatif. Dalam LKPD siswa secara langsung menemukan sendiri suatu konsep melalui kegiatan yang dilakukan, sehingga mereka dapat memahami konsep tersebut tanpa perlu menghapalkannya (Sagita et al., 2020).

Berdasarkan observasi yang dilakukan di kelas IV SD Negeri 1 Baturiti, didapatkan hasil bahwa dalam proses pembelajaran memang sudah menggunakan LKS/LKPD, namun LKPD yang digunakan tidak dikembangkan oleh guru melainkan menggunakan LKPD yang dibuat oleh penerbit. LKPD yang disusun penerbit biasanya belum sesuai dengan karakteristik dan lingkungan siswa karena kurang memiliki keterkaitan dengan masalah nyata yang dihadapi siswa (Indriani et al., 2017; Nur Azizah, 2017). Selain itu, LKPD yang beredar di lapangan hanya berupa lembaran soal dan minim penjelasan materi. Gambar yang tersedia di LKPD masih minim dan berwarna hitam putih sehingga menyebabkan siswa kurang memahami dan menyebabkan LKPD ini kurang menarik bagi siswa. Selain itu, LKPD yang digunakan hanya pemberian materi berbentuk rumus langsung, sehingga siswa tidak memahami cara menemukan konsep yang akan dipelajari (Rahmah et al., 2021). Hal ini akan mengakibatkan kegiatan belajar dalam LKPD terasa monoton dan kurang variatif karena LKPD belum memberikan motivasi kepada siswa untuk mengembangkan ide dan pengalamannya sendiri (Effendi et al., 2021; Septian et al., 2019). Apabila LKPD yang digunakan masih konvensional, maka akan berdampak pada proses pembelajaran. Siswa tidak merasa termotivasi dalam belajar karena LKPD yang digunakan belum memberikan pengalaman belajar yang berpusat pada siswa.

Pada umumnya dalam LKPD terdapat petunjuk praktikum, materi, dan soal-soal latihan yang dapat mengajak siswa aktif dalam proses pembelajaran (Rizkiah et al., 2018). LKPD digunakan untuk mengarahkan siswa dalam menemukan konsep yang dipelajari, sehingga pembelajaran bersifat kontruktivis dan akan membantu guru mencapai tujuan pembelajaran (Apertha et al., 2018; Muthoharoh et al., 2017). Kontruktivis merupakan salah satu komponen pendekatan kontekstual yang pembelajarannya lebih menekankan kepada aktivitas siswa untuk membangun pengetahuannya sendiri. Pengetahuan ini dibangun siswa berdasarkan pengalaman nyata yang dialaminya dengan menyelesaikan masalah, menemukan sesuatu, dan menumbuhkan ide (Kurniati et al., 2015). Pendekatan kontekstual sebagai fokus dalam kegiatan pembelajaran. Siswa terlibat pembelajaran aktif yang didalamnya mampu menemukan makna, karena pembelajaran menghubungkan isi pelajaran dengan lingkungan dan memungkinkan terjadinya proses belajar yang di dalamnya siswa mengeksplorasikan pemahaman serta kemampuan akademiknya (Desi Putrianasari \& Wasitohadi, 2015; Sulianto, 2008). Pembelajaran bermakna berkaitan erat dengan pembelajaran kontekstual, yaitu pembelajaran yang didukung situasi atau masalah dalam kehidupan nyata (Gazali, 2016). Mengingat pentingnya LKPD dalam proses pembelajaran, maka perlu dikembangkannya LKPD dengan pendekatan kontekstual. Hasil penelitian yang diperoleh dari pengembangan LKPD ini sesuai dengan temuan penelitian sebelumnya yang menyatakan bahwa pengembangan LKPD berbasis masalah kontekstual materi masalah sosial kelas IV SD dinyatakan valid dan layak digunakan (Rai et al., 2021). Penelitian lain menunjukkan LKPD dengan pendekatan kontekstual sangat layak digunakan dalam mempelajari materi perubahan lingkungan di SMA (Syarifah \& Iswari, 2021). Penggunaan LKPD berbasis kontekstual pada materi faktorisasi aljabar berdampak positif bagi siswa karena sesuai dengan karakteristik siswa dan lingkungan sosial siswa yang memungkinkan motivasi dalam mempelajari matematika (Zulyadaini, 2017).

Salah satu kemampuan yang harus dimiliki siswa adalah berpikir kritis. Pentingnya berpikir kritis bagi siswa yaitu agar siswa dapat memecahkan segala permasalahan yang ada di dalam dunia nyata dan membuat siswa menjadi lebih mandiri, percaya diri, dan mampu memcahkan persoalan dengan bijak (Kaliky \& Juhaevah, 2018; Oktaviani et al., 2018). Dalam LKPD kontekstual diberikan masalah kepada siswa, sehingga siswa harus berpikir kritis dalam menyelesaikan masalah tersebut. Materi pembelajaran dalam LKPD disajikan dengan gambar pendukung yang menarik agar siswa lebih termotivasi dan mudah 
memahami. Biasanya lembar kerja peserta didik banyak yang monoton dan tidak menarik karena tidak ada gambar dan warna, sehingga keinginan belajar siswa menjadi kurang (Wandari et al., 2018). Materi pembelajaran diawali dengan pemberian masalah kepada siswa. Dengan demikian, siswa dapat berpikir secara kritis untuk memecahkan masalahnya sendiri. Kemampuan berpikir kritis dapat menjadikan manusia untuk lebih menganalisis terlebih dahulu suatu informasi yang baru didapat dan mencari tahu sumber informasi, setelah itu mencari cara dalam penyelesaian masalah tersebut (Dewi et al., 2018). Masalah yang terdapat di LKPD merupakan masalah kontekstual yang terdapat dalam kehidupan sehari-hari siswa. Ini dilakukan agar siswa dapat mengaitkan materi pembelajaran dengan kehidupannya sehari-hari. Makna yang terdapat dalam masalah kontekstual membuat masalah lebih mudah disalurkan dan lebih mungkin melibatkan siswa dalam pembelajaran (Widjaja, 2013).

LKPD yang dikembangkan ini pada mata pelajaran Matematika materi menentukan keliling dan luas persegi, persegi panjang, dan segitiga. Matematika merupakan ilmu yang abstrak, sehingga LKPD dengan pendekatan kontekstual ini cocok digunakan untuk mempermudah menjelaskan materi. Pembelajaran dengan LKPD berbasis kontekstual sangatlah penting dilakukan pada mata pelajaran Matematika SD. Hal ini karena LKPD berbasis kontekstual ini dilengkapi dengan gambar dan warna menarik yang mendukung proses pembelajaran. Selain it, LKPD juga dilengkapi dengan petunjuk pembelajaran agar proses pembelajaran lebih terarah dan terstruktur. Pada mata pelajaran Matematika diperlukan pendekatan yang nyata agar siswa dapat mengaitkan materi matematika dengan lingkungannya sehari-hari. Oleh karena itu, tujuan penelitian ini yaitu untuk mengetahui langkah-langkah pengembangan LKPD berbasis kontekstual dan mengetahui validitas LKPD yang telah dikembangkan.

\section{METODE}

Penelitian ini merupakan penelitian pengembangan (Research and Development) yang bertujuan untuk mengembangkan Lembar Kerja Peserta Didik (LKPD) dengan pendekatan kontekstual pada mata pelajaran Matematika materi menentukan keliling dan luas bangun datar persegi, persegi panjang, dan segitiga. Dalam penelitian ini menggunakan model ADDIE. Menurut (Mulyatiningsih, 2012) ADDIE merupakan singkatan dari Analysis, Design. Development, Implementation, dan Evaluation. Menurut langkah-langkah pengembangan produk, model penelitian dan pengembagan ini lebih rasional dan lebih lengkap daripada model 4D. Model ADDIE dikembagkan oleh Dick \& Carry (1996) untuk merancang sistem pembelajaran. Pemilihan model ini didasari atas pertimbangan bahwa model ini dikembangkan secara sistematis. Model ini disusun secara terprogram dengan urutan-urutan kegiatan yang sistematis dalam upaya pemecahan masalah belajar yang berkaitan dengan bahan ajar yang sesuai dengan kebutuhan dan karakteristik siswa. Kelima tahapan model ADDIE dapat dilihat pada Gambar 1.

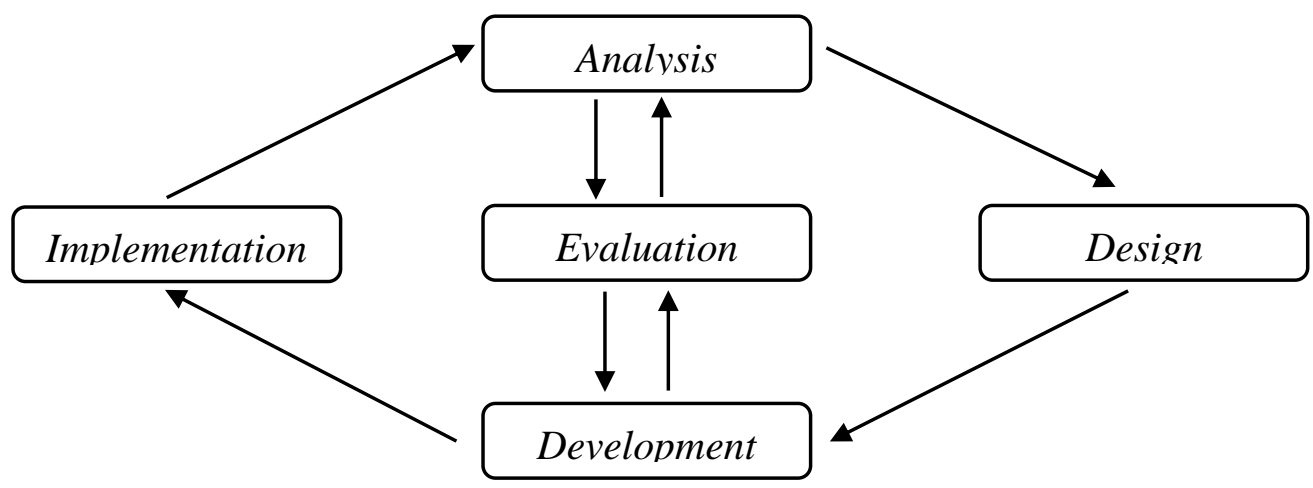

Gambar 1. Tahapan Model ADDIE (Tegeh \& Kirna, 2013)

Pertama yaitu tahap analisis (analysis). Pengembangan ini diawali dengan adanya masalah dalam pengembangan LKPD yang ada di lapangan. Pada tahap ini dilakukan beberapa aktivitas yaitu: pra perencanaan: pemikiran tentang produk baru (bahan ajar berupa LKPD kontekstual) yang akan dikembangkan, mengidentifikasi produk yang sesuai dengan sasaran peserta didik dan tujuan belajar, mengidentifikasi isi/materi pembelajaran dilakukan dengan menganalisis KI dan KD dan mengidentifikasi lingkungan belajar dan strategi penyampaian dalam pembelajaran sehingga materi yang disampaikan dalam LKPD dapat tepat sasaran. Setelah analisis kebutuhan, maka tahap selanjutnya adalah tahap perancangan (design). Pada tahap inilah dilakukan penentuan materi dan pemilihan background, gambar, tulisan, dan komponen lainnya yang mendukung dan sesuai dengan karakteristik siswa. Pembuatan storyboard juga dilakukan untuk mempermudah pembuatan LKPD. Tahap Ketiga yaitu tahap 
pengembangan (development). Pada tahap ini dilakukan beberapa aktivitas yaitu mengembangkan perangkat produk (materi/bahan dan alat) yang diperlukan dalam pengembangan. Adapun bahan/materi tersebut didapatkan dari buku siswa dan buku guru Matematika kelas IV serta LKS Matematika yang digunakan di sekolah. Selain itu, dilakukan pemilihan gambar-gambar yang sesuai dengan materi, berbasis pada hasil rancangan produk. Pada tahap ini mulai dibuat produknya (materi/bahan, alat) yang sesuai dengan struktur model. Setelah produk sudah jadi, maka selanjutnya dirancang instrumen untuk mengukur kinerja produk yang sudah dikembangkan.

Tahap keempat yaitu tahap implementasi (implementation). Pada tahap ini, diimplementasikan rancangan dan metode yang telah dikembangkan pada situasi yang nyata yaitu di kelas. Pada tahap implementasi atau penerapan LKPD kontekstual yang telah dikembangkan untuk mengetahui respon ahli dan siswa dari segi kemenarikan dan kelayakan. Tahap implementasi produk ini dilakukan beberapa hal di antaranya: uji validitas produk oleh para ahli, yaitu ahli isi mata pelajaran yang terdiri dari dosen matematika dan guru matematika serta ahli media pembelajaran, uji coba produk, yang meliputi uji perorangan yang melibatkan tiga orang siswa. Uji coba ini bertujuan untuk mengetahui kualitas dan kelayakan LKPD yang sedang dikembangkan. Tahap terakhir yaitu tahap evaluasi (evaluation). Tahap ini didapatkan dari pihak pengguna LKPD kontekstual yang dikembangkan. Tahap evaluasi dilakukan dalam dua bentuk yaitu evaluasi formatif dan evaluasi sumatif. Namun, pada penelitian ini hanya menggunakan evaluasi formatif karena jenis evaluasi ini berhubungan dengan tahapan penelitian pengembangan untuk memperbaiki produk pengembangan yang dihasilkan. Hasil evaluasi formatif berupa penilaian yang mencangkup validasi ahli materi pembelajaran, ahli media pembelajaran, dan uji coba perorangan. Hasil evaluasi tersebut digunakan untuk memberi umpan balik terhadap pengguna produk baru yang dikembangkan. Revisi dibuat sesuai dengan kebutuhan yang belum dapat dipenuhi oleh produk baru yang dikembangkan tersebut. Metode pengumpulan data dalam penelitian ini adalah metode kuesioner/angket dan pedoman wawancara. Pedoman wawancara meliputi daftar pertanyaan yang diajukan kepada guru kelas IV SD Negeri 1 Baturiti pada saat observasi di lapangan. Metode kuesioner digunakan untuk mengetahui validitas produk yang dikembangkan. Instrumen pengumpulan data yang digunakan pada penelitian pengembangan ini adalah kuesioner. Adapun kisi-kisi instrumen penilaian dari produk LKPD ini sebagai berikut.

Tabel 1. Kisi-Kisi Instrumen Ahli Mata Pelajaran

\begin{tabular}{clc}
\hline Aspek & \multicolumn{1}{c}{ Komponen } & Jumlah butir \\
\hline Kurikulum & KI \& KD & 3 \\
& $\begin{array}{l}\text { Tujuan pembelajaran } \\
\text { Materi }\end{array}$ & Kesesuaian materi \\
& Keluasan dan kedalaman materi & 4 \\
Visualisasi & Kesesuaian gambar untuk mempelajari isi & 3 \\
Bahasa & Kejelasan penggunaan bahasa & 2 \\
Evaluasi & Kesesuaian evaluasi dengan materi & 3 \\
& Kesesuaian tingkat kesulitan soal dengan kompetensi & \multicolumn{1}{c}{ Jumlah } \\
\hline
\end{tabular}

(Sumber: Dimodifikasi dari Parmiti, 2014)

Tabel 2. Kisi-Kisi Instrumen Ahli Media

\begin{tabular}{|c|c|c|}
\hline Aspek & Komponen & Jumlah butir \\
\hline Tampilan & Kemenarikan sampul & 2 \\
\hline & Kesesuaian desain dengan karakteristik peserta didik & \\
\hline Teks & $\begin{array}{l}\text { Kesesuaian Ukuran Huruf } \\
\text { Keterbacaan teks } \\
\text { Kesesuaian jenis huruf }\end{array}$ & 3 \\
\hline Gambar & $\begin{array}{l}\text { Kejelasan gambar } \\
\text { Kesesuaian gambar }\end{array}$ & 2 \\
\hline Warna & $\begin{array}{l}\text { Kekontrasan warna teks } \\
\text { Kesesuaian warna gambar }\end{array}$ & 2 \\
\hline Tata Letak & $\begin{array}{l}\text { Tata letak teks konsisten di setiap halaman } \\
\text { Tata letak komponen di setiap halaman harmonis }\end{array}$ & 2 \\
\hline & Jumlah & 11 \\
\hline
\end{tabular}

Tabel 3. Kisi-Kisi Instrumen Perorangan

(Sumber: Dimodifikasi dari Parmiti, 2014) 


\begin{tabular}{|c|c|c|}
\hline Aspek & Komponen & Jumlah butir \\
\hline Visualisasi & Kemenarikan media pembelajaran & 1 \\
\hline \multirow[t]{3}{*}{ Penyajian Materi } & Kemudahan memahami materi. & 3 \\
\hline & Kejelasan uraian materi & \\
\hline & Keseimbangan materi dengan evaluasi & \\
\hline \multirow[t]{2}{*}{ Teks } & Kualitas teks yang digunakan & 2 \\
\hline & Kejelasan teks yang digunakan & \\
\hline \multirow[t]{2}{*}{ Gambar } & Kualitas gambar yang digunakan & 2 \\
\hline & Kejelasan gambar yang digunakan & \\
\hline Motivasi & Memberikan semangat/motivasi dalam belajar & 1 \\
\hline \multirow[t]{2}{*}{ Evaluasi } & Kesesuaian soal & 1 \\
\hline & Jumlah & 10 \\
\hline
\end{tabular}

Teknik analisis data yang digunakan dalam penelitian ini adalah analisis data kualitatif dan analisis data kuantitatif. Metode analisis kualitatif ini digunakan untuk mengolah data hasil review ahli materi, ahli media pembelajaran, dan pendidik serta uji coba perorangan.. Sedangkan metode analisis kuantitatif digunakan untuk mengolah data yang diperoleh melalui angket dalam bentuk persentase. Persentase yang diperoleh, selanjutnya dikonversikan menggunakan pedoman konversi skala lima untuk mengetahui validitas bahan ajar yang dikembangkan. Pedoman konversi skala lima dapat dilihat pada Tabel 4.

Tabel 4. Konversi Tingkat Pencapaian dengan Skala Lima

\begin{tabular}{cccll}
\hline $\begin{array}{c}\text { Tingkat } \\
\text { Pencapaian } \%\end{array}$ & $\begin{array}{c}\text { Nilai } \\
\text { angka }\end{array}$ & Nilai huruf & \multicolumn{1}{c}{ Kualifikasi } & Keterangan \\
\hline $90-100$ & 4 & A & Sangat Baik & Tidak perlu direvisi \\
$75-89$ & 3 & B & Baik & Tidak perlu direvisi \\
$65-74$ & 2 & C & Cukup & Direvisi \\
$55-64$ & 1 & D & Kurang & Direvisi \\
$0-54$ & 0 & E & Sangat Kurang & Direvisi \\
\hline
\end{tabular}

\section{HASIL DAN PEMBAHASAN}

\section{Hasil}

Hasil pengembangan ini berupa LKPD berbasis pendekatan kontekstual pada mata pelajaran Matematika materi menentukan keliling dan luas bangun datar persegi, persegi panjang, dan segitiga. Adapun hasil analisis data yang diperoleh dari uji ahli dan uji coba produk yaitu produk LKPD ini dinilai oleh seorng ahli mata pelajaran dosen matematika. Dalam melakukan uji ahli mata pelajaran ini menggunakan instrumen pengumpulan data berupa angket/kuesioner. Data yang diperoleh kemudian dikonversikan pada tabel konversi tingkat pencapaian dengan skala lima. Persentase tingkat pencapaiannya yaitu $92 \%$ dengan kualifikasi sangat baik sehingga tidak perlu direvisi. Setelah dilakukannya uji ahli mata pelajaran terhadap dosen Matematika, uji ahli mata pelajaran juga dilakukan kepada guru Matematika di SD Negeri 1 Baturiti. Instrument yang digunakan untuk melakukan uji ahli isi mata pelajaran ini adalah lembar angket/kuesioner. Metode yang digunakan untuk mengumpulkan data adalah metode kuesioner. Data yang diperoleh kemudian dikonversikan pada tabel konversi tingkat pencapaian dengan skala lima. Persentase tingkat pencapaiannya yaitu 97,3\% dengan kualifikasi sangat baik sehingga tidak perlu direvisi. Setelah dilakukannya uji ahli isi mata pelajaran, pada pengembangan akhir dari LKPD juga perlu untuk dilakukan uji ahli media pembelajaran. Instrumen pengumpulan data yang digunakan untuk uji ahli media pembelajaran ini adalah lembar angket/kuesioner Data yang diperoleh kemudian dikonversikan pada tabel konversi tingkat pencapaian dengan skala lima. Persentase tingkat pencapaiannya yaitu 90,9\% dengan kualifikasi sangat baik sehingga tidak perlu direvisi. Uji coba perorangan dilakukan setelah tahap review ahli. Pada tahap uji coba perorangan ini dilakukan oleh tiga orang siswa kelas IV SD Negeri 1 Baturiti. Data yang diperoleh dari uji coba perorangan dari tiga orang siswa mendapatkan rata-rata persentase $96 \%$ dengan kualifikasi sangat baik sehingga tidak perlu direvisi.

Revisi produk dilakukan setelah produk dinilai validitasnya oleh para ahli. Revisi produk ini dilakukan untuk memperbaiki produk yang telah dikembangkan agar sesuai dengan karakteristik peserta didik dan dapat meningkatkan pemahaman peserta didik terhadap materi pembelajaran matematika. 
Adapun masukan/komentar/saran yang diberikan berkenaan dengan kualitas bahan ajar LKPD dengan pendekatan kontekstual dapat dipertimbangkan dan digunakan untuk memperbaiki dan menyempurnakan LKPD yang dikembangkan. Adapun revisi dari ahli dan siswa dijabarkan sebagai berikut. Pada uji ahli mata pelajaran, LKPD dengan pendekatan kontekstual memperoleh persentase $92 \%$ berada pada kualifikasi sangat baik, sehingga tidak perlu dilakukan revisi. Namun, terdapat masukan, saran, dan komentar yang diberikan oleh ahli mata pelajaran terhadap produk yang dikembangkan. Adapun komentar yang diberikan oleh ahli mata pelajaran dosen matematika yaitu: tambahkan soal HOTS pada latihan soal. Perbaikan yang dilakukan adalah menambahkan soal HOTS pada setiap latihan soal. Adapun tampilan atau visualisasi revisi produk dari ahli mata pelajaran dosen matematika yaitu sebagai berikut.

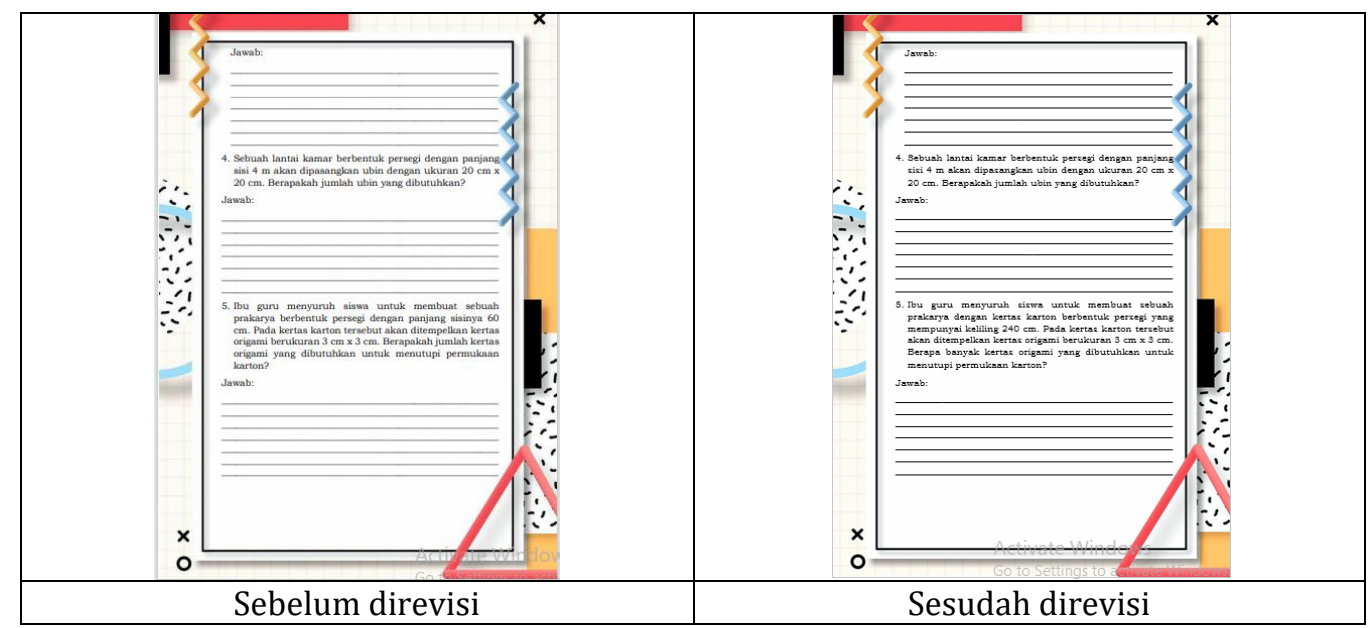

Gambar 2. Menambahkan soal HOTS pada latihan soal

Pada uji ahli mata pelajaran guru matematika memperoleh persentase tingkat pencapaian sebesar 97,3\% berada pada kualifikasi sangat baik, sehingga tidak perlu dilakukan revisi. Adapun komentar yang diberikan oleh ahli mata pelajaran guru matematika yaitu: LKPD sudah bagus dan menarik. Berdasarkan analisis terhadap komentar, masukan dan saran dari ahli mata pelajaran guru matematika tidak ada saran yang bersifat revisi. Pada uji ahli media pembelajaran, LKPD dengan pendekatan kontekstual memperoleh persentase $90,9 \%$ berada pada kualifikasi sangat baik, sehingga tidak perlu dilakukan revisi. Namun, terdapat masukan, saran, dan komentar yang diberikan oleh ahli media pembelajaran terhadap produk yang dikembangkan. Adapun komentar yang diberikan oleh ahli media pembelajaran yaitu: tujuan pembelajaran 1 tertutup judul tujuan pembelajaran dan setiap topik diberikan juga tujuan pembelajaran, tidak hanya indikator saja. Berdasarkan komentar tersebut maka dilakukan perbaikan terhadap produk yang dikembangkan. Adapun perbaikan yang dilakukan yaitu: memperbaiki tujuan pembelajaran 1 yang tertutup judul tujuan pembelajaran, dan menambahkan tujuan pembelajaran pada setiap topik. Adapun tampilan atau visualisasi revisi produk dari ahli media pembelajaran yaitu sebagai berikut.

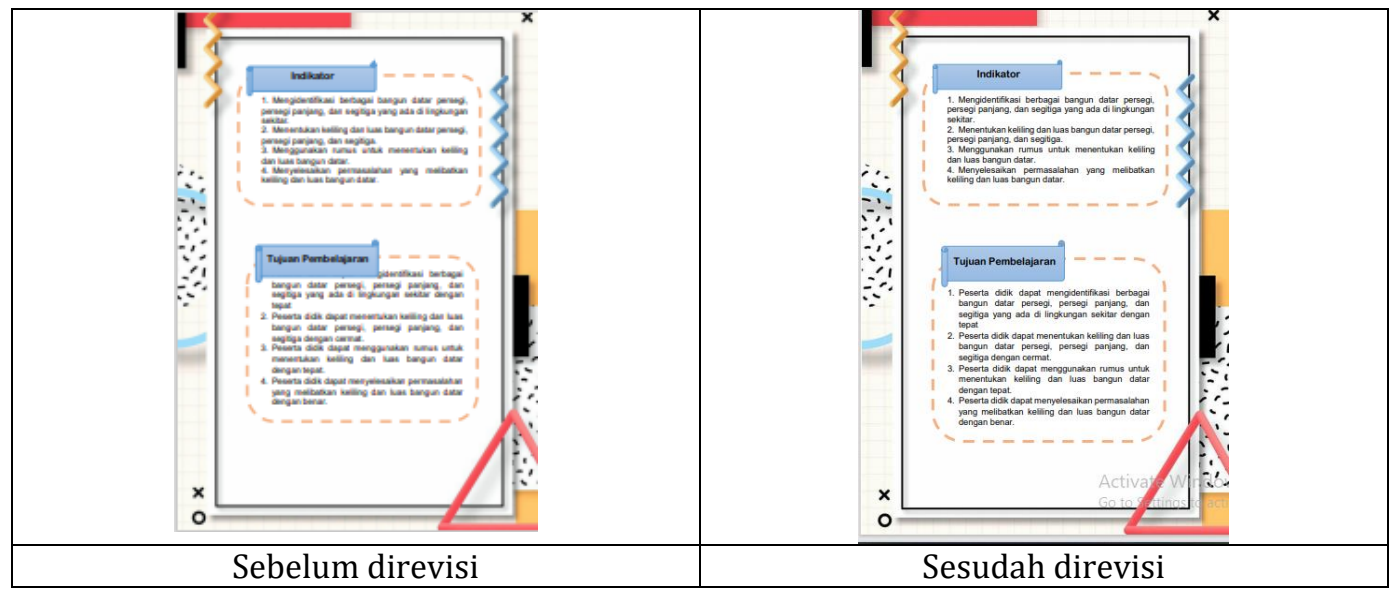

Gambar 3. Revisi Pengetikan Tujuan Pembelajaran yang Tertutup Judul 


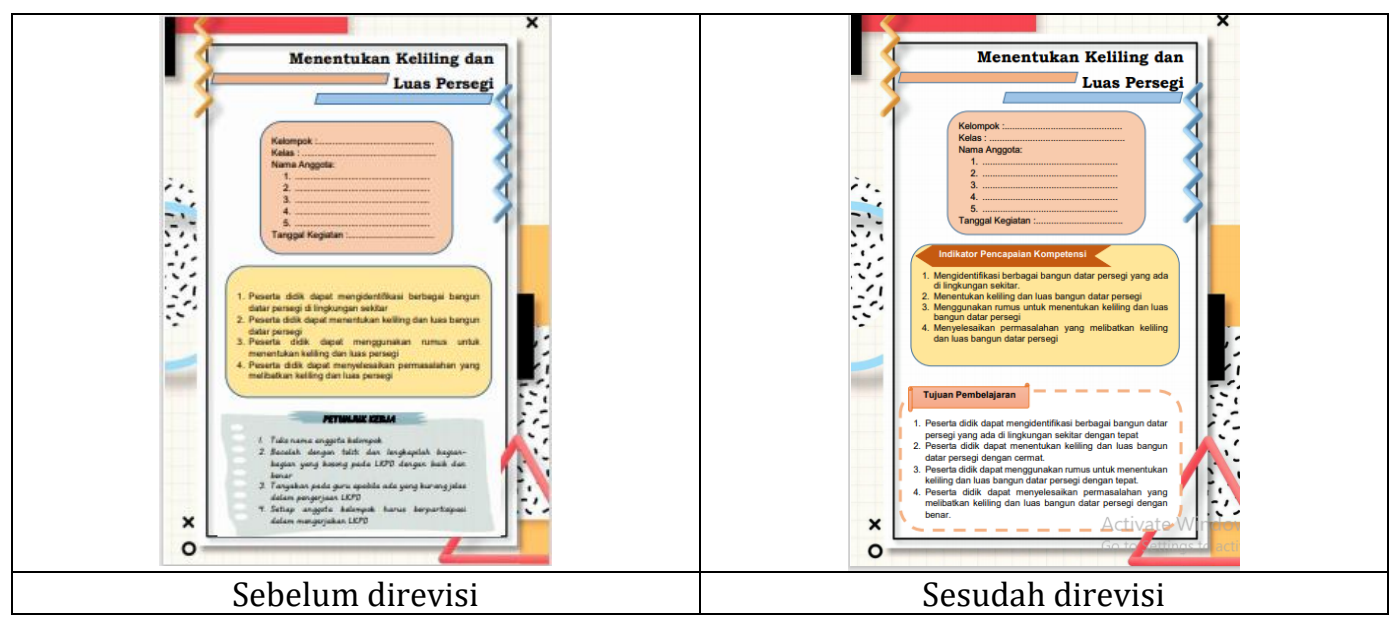

Gambar 4. Revisi Menambahkan Tujuan Pembelajaran di Setiap Topik

Pada uji coba LKPD dengan pendekatan kontekstual memperoleh persentase tingkat pencapaian sebesar $96 \%$ berada pada kualifikasi sangat baik, sehingga tidak perlu dilakukan revisi. Adapun komentar dari uji coba perorangan yaitu: gambar yang digunakan menarik, pembelajaran jadi seru, warna dan gambar bagus. Berdasarkan analisis terhadap komentar, masukan dan saran dari uji coba perorangan tidak ada saran yang bersifat revisi. Berdasarkan hasil peneliian yang telah dilakukan, LKPD berbasis kontekstual memperoleh kualifikasi sangat baik dari aspek isi mata pelajaran. LKPD yang dikembangkan sudah mengacu kepada aspek kurikulum, materi, visualisasi, bahasa, dan evaluasi. Materi yang digunakan dalam LKPD berbasis kontekstual ini sudah sesuai dengan yang terdapat di kurikulum dan sejalan dengan tujuan pembelajaran yang akan dicapai. Selain itu, materi yang dijelaskan dalam LKPD sesuai dengan karakteristik peserta didik yang dilengkapi dengan ilustrasi gambar dan warna yang menarik, sehingga siswa dapat termotivasi dalam belajar. Karakteristik anak pada usia 7-11 tahun yaitu menggunakan bahasa yang sederhana, memuat visualisasi yang menarik sesuai dengan perkembangan emosi dan intelektual, dirancang dengn warna-warna cerah (Rosita, 2015). Pemilihan bahasa yang tepat untuk membuat suatu kalimat sangat penting dalam mengembangkan LKPD. Dalam LKPD guru perlu menggunakan kalimat-kalimat yang tidak terlalu panjang, tidak rumit, dengan kata-kata sederhana yang mudah dipahami siswa serta kalimat positif (Rofiah, 2014).

Hasil validasi LKPD berbasis kontekstual dari aspek media pembelajaran berada pada kualifikasi sangat baik. Pada aspek media pembelajaran dinilai beberapa hal yaitu tampilan, teks, gambar, warna, dan tata letak. LKPD yang telah dikembangkan menggunakan sampul yang menarik dengan dilengkapi warnawarna yang cerah dan ukuran huruf yang mudah dibaca peserta didik. Dengan warna yang bagus dan menarik, peserta didik merasa senang belajar menggunakan LKPD (Juniati et al., 2021). Huruf yang digunakan dalam menjelaskan materi LKPD yaitu huruf Arial font 16. Dengan ukuran huruf yang lumayan besar, siswa akan lebih mudah membaca teks. Gambar yang digunakan dalam LKPD merupakan gambar yang kontekstual seperti gambar uang, gambar papan catur, dan lain sebagainya yang disajikan dalam bentuk kartun. Gambar kartun memang sangat digemari oleh anak-anak. Gambar yang menarik dan lucu akan membuat siswa antusias dalam proses pembelajaran (Mahardika et al., 2012). Tata letak yang digunakan dalam LKPD juga harmonis antara satu komponen dengan komponen lainnya. Hasil uji coba LKPD berbasis kontekstual dilakukan hanya sampai uji coba perorangan yang terdiri dari 3 orang siswa kelas IV SD Negeri 1 Baturiti berada pada kualifikasi sangat baik. Sampul LKPD berbasis kontekstual ini sangat menarik bagi siswa karena dihiasi dengan warna dan gambar yang menarik. Dengan menggunakan media gambar dalam belajar matematika ini motivasi siswa dapat meningkat, karena ditunjang dengan bentuk media yang menarik, dan juga mempunyai macam-macam warna, sehingga menimbulkan proses belajar yang aktif, kreatif, dan menyenangkan (Istiningsih et al., 2018). Uraian yang ada pada LKPD juga mudah dipahami oleh siswa, isinya jelas, dan mudah dibaca siswa karena ukuran font cukup besar. Dalam LKPD juga terdapat petunjuk penggunaan LKPD yang mudah dipahami oleh siswa. Selain itu, LKPD ini dapat meningkatkan motivasi siswa dalam belajar karena didalamnya terdapat kalimat-kalimat rumpang yang menuntut siswa untuk berpikir kritis. Pemberdayaan kemampuan berpikir kritis dalam pembelajaran perlu dikembangkan untuk mempersiapkan siswa agar menjadi pemecah masalah yang tangguh, pembuat keputusan yang matang, dan orang yang tidak pernah berhenti untuk belajar (Adiwijaya et al., 2016).

Hasil penelitian yang diperoleh dari pengembangan LKPD ini sesuai dengan temuan penelitian sebelumnya yang menyatakan bahwa pengembangan LKPD berbasis masalah kontekstual pada materi 
masalah sosial kelas IV SD dinyatakan valid dan layak digunakan (Rai et al., 2021). Penelitian lain menunjukkan LKPD dengan pendekatan kontekstual sangat layak digunakan dalam mempelajari materi perubahan lingkungan di SMA (Syarifah \& Iswari, 2021). Penggunaan LKPD berbasis kontekstual pada materi faktorisasi aljabar berdampak positif bagi siswa karena sesuai dengan karakteristik siswa dan lingkungan sosial siswa yang memungkinkan motivasi dalam mempelajari matematika (Zulyadaini, 2017). Penggunaan pendekatan kontekstual juga didasari oleh beberapa penelitian sebelumnya yang berdampak positif dalam pembelajaran yaitu berpengaruh dalam meningkatkan keterampilan berpikir kritis siswa serta dapat meningkatkan keaktifan dan hasil belajar matematika pada siswa (Sulianto, 2008; Taurina \& Wasitohadi, 2015). Lembar Kerja Peserta Didik (LKPD) berbasis kontekstual ini dikembangkan untuk memudahkan siswa memahami materi matematika yang abstrak. Selain itu, LKPD ini dapat mempermudah penyampaian materi oleh guru kepada siswa karena dalam LKPD ini siswa dapat mengontruksi pengetahuannya sendiri, sehingga siswa menjadi lebih aktif. LKPD yang dikembangangkan dilengkapi dengan gambar dan warna yang cerah dan menarik, sehingga dapat menarik perhatian siswa dalam proses pembelajaran. Produk LKPD matematika berbasis kontekstual ini dalam penilaian pada umumnya mendapatkan kualifikasi sangat baik. Namun, dalam pengembangannya masih terdapat beberapa kelemahan. Kelemahan itu terdapat pada uji coba produk, yang hanya melakukan uji coba perorangan sebanyak 3 orang siswa kelas IV SD N 1 Baturiti.

\section{SIMPULAN}

Berdasarkan pemaparan hasil dan pembahasan dapat disimpulkan bahwa LKPD berbasis kontekstual valid dan layak digunakan dengan kategori sangat baik dilihat dari aspek materi pembelajaran, media pembelajaran, dan uji coba perorangan. Adapun saran yang ingin dikemukakan kepada siswa dan guru agar memanfaatkan LKPD berbasis kontekstual ini sebaik mungkin dalam proses pembelajaran, sehingga pembelajaran menjadi lebih bermakna.

\section{DAFTAR PUSTAKA}

Adiwijaya, H., Suarsini, E., \& Lukiati, B. (2016). Penerapan Pembelajaran Reciprocal Teaching Berbantuan Peta Konsep untuk Meningkatkan Kemampuan Berpikir Kritis Siswa pada Pembelajaran Biologi. Jurnal Pendidikan: Teori, Penelitian, Dan Pengembangan, 1(12), 2379-2387-2387. http://journal.um.ac.id/index.php/jptpp/article/view/8359/4004.

Ambarini, N., Rosyidi, A., \& Ariyanto, J. (2013). The Implementation of Card Sort Active Learning with Mind Mapping to Increase Students' Learning Interest in Biology at the Students' of VII-E SMP Negeri 5 Surakarta. BIO-PEDAGOGI, 2(1), 77. https://doi.org/10.20961/bio-pedagogi.v2i1.5280.

Apertha, F. K. P., Zulkardi, \& Yusup, M. (2018). Pengembangan LKPD Berbasis Open-Ended Problem pada Materi Segiempat Kelas VII. In Jurnal Pendidikan Matematika (Vol. 12, Issue 2, pp. 47-62). https: //core.ac.uk/download/pdf/267822059.pdf.

Astriani, L. (2017). Pengaruh Pembelajaran Reciprocal Teaching terhadap Kemampuan Pemahaman Konsep Matematika Ditinjau dari Kemampuan Awal Matematika Siswa. FIBONACCI Pendidikan Matematika Dan Matematika, 3(1), 77-85. http://jurnal.m.ac.id/index.php/fbc.Desi Putrianasari, D., \& Wasitohadi, W. (2015). Pengaruh Penerapan Pendekatan Contextual Teaching and Learning (CTL) terhadap Hasil Belajar Matematika Ditinjau dari Motivasi Belajar Siswa Kelas 5 SD Negeri Cukil 01 Kecamatan Tengaran - Kabupaten Semarang. Scholaria: Jurnal Pendidikan Dan Kebudayaan, 5(1), 57. https://doi.org/10.24246/j.scholaria.2015.v5.i1.p57-77.

Dewi, W. S., Supriadi, N., \& Putra, F. G. (2018). Model Hands on Mathematics (HoM) Berbantuan LKPD Bernuansa Islami Materi Garis dan Sudut. Desimal: Jurnal Matematika, 1(1), 57. https://doi.org/10.24042/djm.v1i1.1913.

Effendi, R., Herpratiwi, H., \& Sutiarso, S. (2021). Pengembangan LKPD Matematika Berbasis Problem Based Learning di Sekolah Dasar. Jurnal Basicedu, 5(2), 920-929. https://doi.org/10.31004/basicedu.v5i2.846.

Fahrurrozi, M., Mohzana, \& Mispandi. (2021). Pengembangan Bahan Ajar Prakarya dan Kewirausahaan Berbasis Kearifan Lokal. Jurnal Pendidikan Ilmu Pengetahuan Sosial Indonesia, 6(1), 7-14. http://dx.doi.org/10.26737/jpipsi.v6i1.2271.

Gazali, R. Y. (2016). Pengembangan Bahan Ajar Matematika untukSsiswa SMP BerdasarkanTteori Belajar Ausubel. PYTHAGORAS: Jurnal Pendidikan Matematika, 11(2), 182. https://doi.org/10.21831/pg.v11i2.10644.

Indriani, M., Niswah, C., \& Arifin, S. (2017). Pengembangan Lembar Kerja Peserta Didik (LKPD) Berbasis Inkuiri Terbimbing pada Materi Transformasi Geometri. Jurnal Pendidikan Matematika RAFA, 
3(2), 165-180. https://doi.org/10.19109/jpmrafa.v3i2.1739.

Istiningsih, S., Fauzy, M., \& Nisa, K. (2018). Penggunaan Media Gambar untuk Meningkatkan Motivasi Belajar Matematika pada Siswa Kelas 1 SDN 1 Kediri Tahun Pelajaran 2017/2018. JKKP Uurnal Kesejahteraan Keluarga Dan Pendidikan), 5(1), 31-41. https://doi.org/10.21009/jkkp.051.04.

Juniati, Kartini, \& Maimunah. (2021). Perangkat Pembelajaran Materi Segiempat dan Segitiga Berbasis Model PBL untuk Memfasilitasi Kemampuan Koneksi Matematis Peserta Didik SMP/MTs. Jurnal Cendekia: Jurnal Pendidikan Matematika, 05(02), 1359-1373. https://doi.org/10.31004/cendekia.v5i2.545.

Kaliky, S., \& Juhaevah, F. (2018). Analisis Kemampuan Berpikir Kritis Siswa Kelas X SMA dalam Menyelesaikan Masalah Identitas Trigonometri Ditinjau dari Gender. Matematika dan Pembelajaran, 6(2), 111. https://doi.org/10.33477/mp.v6i2.663.

Kartika Putra, I. G. L. A., Tastra, I. D. K., \& Suwatra, I. G. N. I. W. (2014). Pengembangan Media Video Pembelajaran dengan Model Addie Pada Pembelajaran Bahasa Inggris di SDN 1 Selat. E-Jurnal Edutech Universitas Pendidikan Ganesha, 2(5). https://doi.org/10.23887/jeu.v2i1.3939.

Kurniati, K., Kusumah, Y. S., Sabandar, J., \& Herman, T. (2015). Mathematical Critical Thinking Ability Through Contextual Teaching And Learning Approach. Journal on Mathematics Education, 6(1), 53-62. https://doi.org/10.22342/jme.6.1.1901.53-62.

Mahardika, I. K., Maryani, \& Citra Murti, S. C. (2012). Penggunaan Model Pembelajaran Creative Problem Solving Disertai Lks Kartun Fisika Pada Pembelajaran Fisika di SMP. Jurnal Pembelajaran Fisika, 1(2), 231-237. http://repository.unej.ac.id/handle/123456789/482.

Mulyatiningsih, E. (2012). Metode Penelitian Terapan Bidang Pendidikan. Alfabeta.

Mustaqim, I., \& Kurniawan, N. (2017). Pengembangan Media Pembelajaran Berbasis Augmented Reality. Jurnal Edukasi Elektro, 1(1), 36-48. https://doi.org/10.24252/lp.2018v21n1i6.

Muthoharoh, M., Kirna, I. M., \& Indrawati, G. A. (2017). Penerapan Lembar Kerja Peserta Didik (LKPD) Berbasis Multimedia untuk Meningkatkan Motivasi dan Hasil Belajar Kimia. Jurnal Pendidikan Kimia Indonesia, 1(1), 13. https://doi.org/10.23887/jpk.v1i1.12805.

Nur Azizah, I. (2017). Lembar Kerja Peserta Didik Materi Aritmatika Sosial dengan Model Pengembangan Thiagarajan. NUMERICAL: Jurnal Matematika Dan Pendidikan Matematika, 1(2), 63-72. https://doi.org/10.25217/numerical.v1i2.132.

Oktaviani, W., Kristin, F., \& Anugraheni, I. (2018). Penerapan Model Pembelajaran Discovery Learning Untuk Meningkatkan Kemampuan Berpikir Kritis Dan Hasil Belajar Matematika Siswa Kelas 5 SD. Jurnal Basicedu, 2(2), 5-10. https://doi.org/10.31004/basicedu.v2i2.137.

Pamungkas, A. S., Setiani, Y., \& Pujiastuti, H. (2017). Peranan Pengetahuan Awal dan Self Esteem Matematis Terhadap Kemampuan Berpikir Logis Mahasiswa. Kreano, Jurnal Matematika KreatifInovatif, 8(1), 61-68. https://doi.org/10.15294/kreano.v8i1.7866.

Parmiti, D. P. (2014). Pengembangan Bahan Ajar. Jurusan Teknologi Pendidikan Fakultas Ilmu Pendidikan Universitas Pendidikan Ganesha.

Purmadi, A., \& Surjono, H. D. (2016). Pengembangan Bahan Ajar Berbasis Web Berdasarkan Gaya Belajar Siswa Untuk Mata Pelajaran Fisika. Jurnal Inovasi Teknologi Pendidikan, 3(2), 151. https://doi.org/10.21831/jitp.v3i2.8285.

Rahmah, A. N., Zulkarnain, \& Hutapea, N. M. (2021). Pengembangan Perangkat Pembelajaran Matematika Berbasis Model Problem Based Learning Untuk Memfasilitasi Kemampuan Komunikasi Matematis Peserta Didik Kelas VII SMP/MTs. Jurnal Cendekia : Jurnal Pendidikan Matematika, 5(1), 125-138. https://doi.org/10.31004/cendekia.v5i1.415.

Rai, I. M., Wiranata, A., \& Sujana, I. W. (2021). Pengembangan Lembar Kerja Peserta Didik Berbasis Pemecahan Masalah Kontekstual Materi Masalah Sosial Kelas IV SD. Jurnal Pedagogi Dan Pembelajaran, 4(1), 30-38. https://ejournal.undiksha.ac.id/index.php/JP2/article/view/31926.

Rizkiah, A. W., Nasir, N., \& Komarudin, K. (2018). LKPD Discussion Activity Terintegrasi Keislaman dengan Pendekatan Pictorial Riddle pada Materi Pecahan. Desimal: Jurnal Matematika, 1(1), 39. https://doi.org/10.24042/djm.v1i1.1926.

Rofiah, N. H. (2014). Pengembangan Lembar Kerja Peserta Didik (Lkpd) Berbasis Kit Untuk Meningkatkan Keterampilan Proses Dasar Ipa Di Mi/Sd. Al-Bidayah, 6(2), 253-272. https://doi.org/10.14421/al-bidayah.v6i2.145.

Rosita, F. Y. (2015). Pengembangan Multimedia Interaktif Untuk Pembelajaran Berbicara Bagi Siswa Kelas IV Sekolah Dasar. JINoP Uurnal Inovasi Pembelajaran), 1(1), 25. https://doi.org/10.22219/jinop.v1i1.2445.

Sagita, D., Sutiarso, S., \& Asmiati, A. (2020). Pengembangan LKPD Pada Model Pembelajaran Kooperatif Tipe TTW untuk Meningkatkan Kemampuan Pemahaman Konsep Matematis Siswa. Jurnal Cendekia: Jurnal Pendidikan Matematika, 4(2), 846-856. 
https://doi.org/10.31004/cendekia.v4i2.309.

Sari, R. T. (2017). Uji Validitas Modul Pembelajaran Biologi Pada Materi Sistem Reproduksi Manusia Melalui Pendekatan Konstruktivisme Untuk Kelas IX SMP. Scientiae Educatia, 6(1), 22. https://doi.org/10.24235/sc.educatia.v6i1.1296.

Septian, R., Irianto, S., \& Andriani, A. (2019). Pengembangan Lembar Kerja Peserta Didik (LKPD) Matematika Berbasis Model Realistic Mathematics Education. Jurnal Educatio FKIP UNMA, 5(1), 59-67. https://doi.org/10.31949/educatio.v5i1.56.

Sulianto, J. (2008). Pendekatan Kontekstual dalam Pembelajaran Matematika Untuk Meningkatkan Berpikir Kritis Pada Siswa Sekolah Dasar. Pythagoras: Jurnal Pendidikan Matematika, 4(2), 14-25. https://doi.org/10.21831/pg.v4i2.555.

Surya, E., Putri, F. A., \& Mukhtar, M. (2016). Improving Mathematical Problem-Solving Ability and SelfConfidence Of High School Students Through Contextual Learning Model. Journal on Mathematics Education, 8(1), 85-94. https://doi.org/10.22342/jme.8.1.3324.85-94.

Syarifah, M. N., \& Iswari, R. S. (2021). Development of CTL-approached Students Activity Worksheet in Environmental Change Learning Material to Increase Students' Learning Outcome. Journal of Biology Education, 10(1), 42-51. https://doi.org/10.15294/jbe.v10i1.41239.

Taurina, N. D., \& Wasitohadi, W. (2015). Upaya Peningkatan Keaktifan dan Hasil Belajar Matematika melalui Pendekatan Contextual Teaching and Learning (CTL) Berbantuan Alat Peraga Pada Siswa Kelas 5 SDN Lodoyong 03 - Ambarawa Tahun Pelajaran 2013/2014. Scholaria : Jurnal Pendidikan Dan Kebudayaan, 5(2), 15. https://doi.org/10.24246/j.scholaria.2015.v5.i2.p15-35.

Tegeh, I. M., \& Kirna, I. M. (2013). Pengembangan Bahan Ajar Metode Penelitian Pendidikan dengan ADDIE Model. Jurnal IKA, 11(1), 16. https://doi.org/10.23887/ika.v11i1.1145.

Wandari, A., Kamid, K., \& Maison, M. (2018). Pengembangan Lembar Kerja Peserta Didik (LKPD) pada Materi Geometri Berbasis Budaya Jambi untuk Meningkatkan Kreativitas Siswa. Edumatika: Jurnal Riset Pendidikan Matematika, 1(2), 47. https://doi.org/10.32939/ejrpm.v1i2.232.

Widjaja, W. (2013). The Use of Contextual Problems to Support Mathematical Learning. Journal on Mathematics Education, 4(2), 151-159. https://doi.org/10.22342/jme.4.2.413.151-159.

Zulyadaini, D. (2017). A Development of Students' Worksheet Based on Contextual Teaching and Learning. IOSR Journal of Mathematics, 13(01), 30-38. https://doi.org/10.9790/5728-1301033038. 